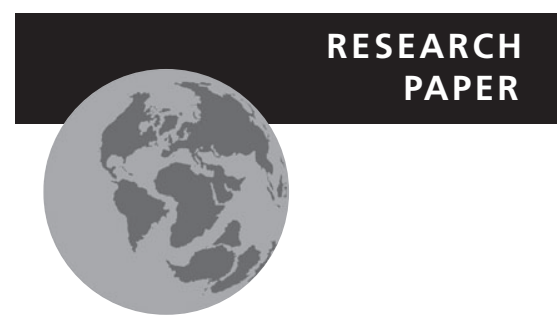

\title{
Anthropogenic and climatic impacts on surface pollen assemblages along a precipitation gradient in north-eastern China
}

Yun Zhang ${ }^{1 \star}$, Zhaochen Kong ${ }^{1}$, Guohong Wang ${ }^{1}$ and Jian $\mathrm{Ni}^{1,2 *}$

${ }^{1}$ State Key Laboratory of Vegetation and Environmental Change, Institute of Botany, Chinese Academy of Sciences, 100093 Beijing, China, ${ }^{2}$ Alfred Wegener Institute for Polar and Marine Research, 14473 Potsdam, Germany

${ }^{*}$ Correspondences: Yun Zhang and Jian Ni, State Key Laboratory of Vegetation and Environmental Change, Institute of Botany, Chinese Academy of Sciences, Xiangshan Nanxincun 20, Beijing 100093, China. E-mails: zhangygl@ibcas.ac.cn; jni@ibcas.ac.cn

\begin{abstract}
Aim To understand the scenarios of 'anthropogenic biomes' that integrate human and ecological systems, we need to explore the impacts of climate and human disturbance on vegetation in the past and present. Interactions among surface pollen, modern vegetation and human activities along climate and land-use gradients are tested to evaluate the natural and anthropogenic forces shaping the modern vegetation, and hence to aid the reconstruction of vegetation and climate in the past. This in turn will help with future predictions.
\end{abstract}

Location The North-east China Transect (NECT) in north-eastern China.

Methods We analysed 33 surface pollen samples and 213 quadrats across four vegetation zones along the moisture/land-use gradients of the NECT. Detrended correspondence analysis (DCA) and redundancy analysis (RDA) of 52 pollen taxa and three environmental variables were used to distinguish anthropogenic and climatic factors that affect surface pollen assemblages along the NECT.

Results The 33 surface samples are divided into four pollen zones (forest, meadow steppe, typical steppe and desert steppe) corresponding to major vegetation types in the NECT. Variations in pollen ratios of fern/herb $(\mathrm{F} / \mathrm{H})$, Artemisial Chenopodiaceae (A/C) and arboreal pollen/non-arboreal pollen (AP/NAP) represent the vegetation and precipitation gradient along the NECT. DCA and RDA analyses suggest that surface pollen assemblages are significantly influenced by the precipitation gradient. Changes in the abundance of Chenopodiaceae pollen are related to both human activities and precipitation.

Main conclusions Surface pollen assemblages, fossil pollen records, archaeological evidence and historical documents in northern China show that a large increase of Chenopodiaceae pollen indicates human-caused vegetation degradation in sandy habitats. The A/C ratio is a good indicator of climatic aridity, but should be used in conjunction with multiple proxies of human activities and climate change in the pollen-based reconstruction of anthropogenic biomes.

\section{Keywords}

Climate gradient, human activities, North-east China Transect (NECT), ordination, redundancy analysis (RDA), surface pollen.

\section{INTRODUCTION}

More than $75 \%$ of Earth's ice-free land surface has been altered as a result of human residence and land use. Consequently, global patterns of biodiversity and ecosystem processes have been fundamentally modified by humans and the world's biomes have therefore become 'anthropogenic biomes' (Ellis \& Ramankutty, 2008). The study of anthropogenic biomes is now an important research direction in Earth system science (Alessa \& Chapin III, 2008), especially with the increasing interest in investigations of the terrestrial biosphere that integrate human and ecological systems, so-called social-ecological systems (Ellis 
\& Ramankutty, 2008). Human-induced climate change together with changes in atmospheric composition and land use have altered the world's ecosystems. Such anthropogenic climate change has happened not only in recent decades but also in the Holocene (Dearing, 2006). Understanding climate-humanenvironmental interactions at local and regional scales is the foundation for fully understanding environmental changes at a global scale, and resolving our past is an essential element in predicting the future (Dearing, 2006).

The fossil pollen record is a good proxy for reconstructing palaeovegetation and palaeoclimate. Modern pollen assemblages connect modern vegetation composition and pattern, and this relationship can be used to infer past patterns and changes. Our ability to understand the nature and extent of current human impacts on vegetation rests on our ability to interpret past vegetation changes. Interpreting past vegetation changes from pollen analysis, in turn, depends on the quality of our understanding about the relationship between modern vegetation and surface pollen assemblages. Such studies have increasingly become local, regional and global concerns (Prentice \& Jolly, 2000). Doing these studies along environmental gradients of climate and land use will be valuable.

The IGBP (International Geosphere-Biosphere Programme) Terrestrial Transects, established in the 1990s, are a set of integrated global change studies consisting of observations and manipulative experiments coupled with modelling and synthesis (Koch et al., 1995). The North-east China Transect (NECT), a moisture and land-use driven mid-latitude semi-arid gradient, is one of the IGBP Terrestrial Transects (Koch et al., 1995; Zhang et al., 1997; Ni \& Zhang, 2000; Ni, 2003). Since the 1980s, much remarkable research on changes of climate, plant species distribution and ecophysiological response, plant functional types and traits, vegetation, land use and land cover, as well as trace gas emission, biomass, net primary production and carbon dynamics has been performed on the NECT (see the synthesis of Ni \& Wang, 2004, and more recent publications, e.g. Fang et al., 2006, and Zhang \& Zhou, 2008).

The main aim of studies of the NECT is to elucidate relationships among modern environments, ecosystems and land use: analyses focusing on the correlations between pollen, vegetation, climate change and human activities at present and in the past have received much less attention. The only such work is a comparison of modern plant communities with surface pollen assemblages along the NECT (Li et al., 2000): a close relationship and $>50 \%$ similarity were found. However, more work should be attempted to understand how relationships between surface pollen assemblages and modern vegetation vary along gradients of precipitation, land-use change and human activities. Such work can contribute to the reconstruction of past vegetation and climate and further understanding of natural and anthropogenic forces in shaping climate change and the terrestrial biosphere of the Earth system.

However, remarkable spatio-temporal climate variations and different intensities and regimes of land-use change at different spatial scales make it difficult to separate human influences from the effects of climate change, both of which are drivers of vegetation changes. The NECT, located in several anthropogenic biomes of dense settlements, villages, croplands, rangeland and forests (Ellis \& Ramankutty, 2008), is no exception. Substantial inter- and intra-annual climate variability (Ni \& Zhang, 2000) and different land-use regimes (pasture, agriculture and forestry) as well as changeable topography (Zhang et al., 1997) result in a very complicated vegetation pattern along the NECT. During the mid-Holocene, the NECT area was settled by only a few people and large populations of animals. With increasing human settlement in the last few hundred years, large areas of grassland and forest have been cultivated for agriculture and forests have been cut down (Zhao et al., 1992; Ren, 2007). There is an urgent need to restore and to protect the natural environment in this region (Ni \& Zhang, 2000; Ni \& Wang, 2004). Distinguishing the effects of human activity from the effects of climate change is a big challenge. But different pollen assemblages have proved to be associated with climate and human factors (Liu et al., 2006; Bradshaw, 2008; Li et al., 2008; Liu et al., 2008a), therefore the study of pollen has become a valuable tool for reconstructing vegetation patterns in the past and to infer the causes of vegetation degradation.

Here, using the NECT along precipitation and land-use gradients as the target study area, we reveal the relationship between modern vegetation and surface pollen assemblages and interpret the complicated interaction between surface pollen and modern vegetation, climate gradients and human activities. Samples of surface pollen are collected and analysed in different climatic and vegetation zones with different intensities of human interference along the NECT. These data are then subjected to statistical analyses in order to distinguish the effects of anthropogenic and climatic factors on surface pollen assemblages.

\section{MATERIALS AND METHODS}

\section{Study area}

The study area is located in the Inner Mongolian Plateau and Jilin Province of China, with latitudes ranging from 42 to $46^{\circ} \mathrm{N}$ and longitudes from 110 to $132^{\circ} \mathrm{E}$ (Fig. 1). The climate of this region is generally continental, but local climate varies along the gradient: it is temperate humid in the south-east, semi-humid and semi-arid in the central section and arid at the northwestern edge (Zhang et al., 1997; Ni \& Zhang, 2000). Modern climatic data (1950s-2000) from 181 meteorological stations in the study area were used to calculate the mean annual temperature (MAT) and precipitation (MAP). Their contour maps (Fig. 2), drawn using the OrIGIN software package version 7.0 (OriginLab, USA), showed that there is an obvious gradient of MAP decreasing gradually from $500-700 \mathrm{~mm}$ in the east, to $300-500 \mathrm{~mm}$ in the middle, and to $100-300 \mathrm{~mm}$ in the west. MAT ranges from $2-6{ }^{\circ} \mathrm{C}$ and does not show an obvious gradient, probably because the NECT is located in a narrow latitudinal zone (Fig. 2).

Vegetation zones in the NECT vary along the steep moisture gradient. Temperate evergreen conifer-deciduous broadleaf 


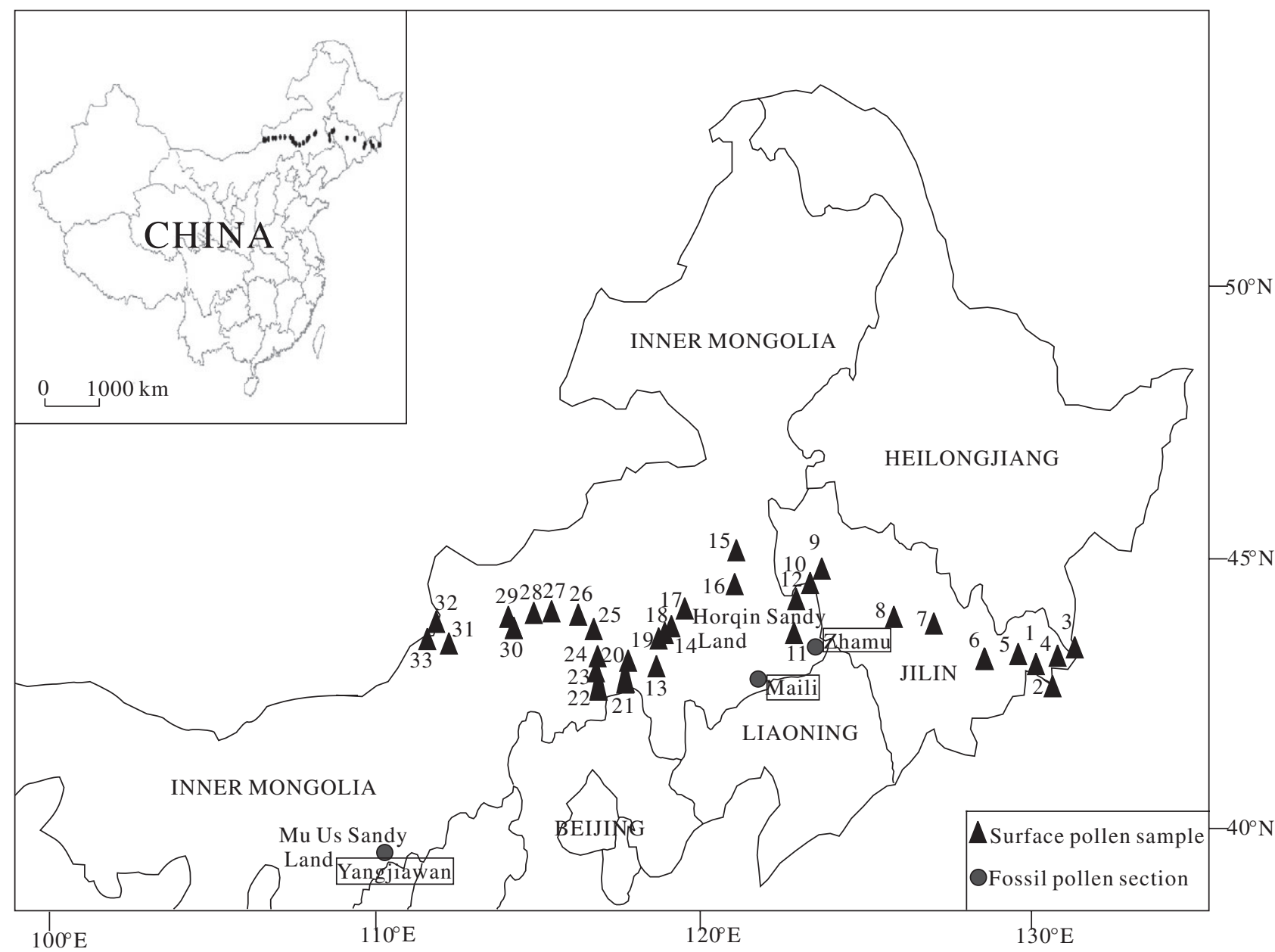

Figure 1 The study area and locations of 33 surface pollen sampling sites along the North-east China Transect (NECT).

mixed forests, dominated by Larix olgensis, Pinus koraiensis, Picea jezoensis and Fraxinus mandshurica, and deciduous broadleaf forests, consisting mainly of Quercus mongolicus and Juglans mandshurica, are distributed in the east. Meadow steppes (mainly Leymus chinensis) and agricultural fields occupy in the middle eastern part of the transect. In the mid-west there are typical steppes with Stipa grandis and Stipa krylovii as the dominants, and at the western end there are desert steppes of Stipa glareosa, Stipa gobica, Salsola collina and Caragana stenophylla (Zhang et al., 1997; Ni \& Zhang, 2000). The current patterns of land use vary in different regions of the NECT, including forestry, agricultural and pastoral areas from east to west (Ni \& Zhang, 2000).

\section{Vegetation survey and collection of surface pollen samples}

A total of 33 sites were investigated in summer 2006 at intervals of $10-50 \mathrm{~km}$ along the NECT (see Appendix S1 in Supporting Information; Fig. 1). Species composition and vegetation structure were surveyed, and surface pollen samples were collected at each site. In each of the eight eastern forest vegetation sites, we surveyed one $10 \times 10 \mathrm{~m}^{2}$ quadrat for the tree layer, five shrub quadrats $\left(5 \times 5 \mathrm{~m}^{2}\right.$ each $)$ and five herb quadrats $\left(2 \times 2 \mathrm{~m}^{2}\right.$ each $)$. In the middle to western steppe vegetation, we investigated 25 sites with five quadrats each. Usually, the quadrat size for grasses was $1 \times 1 \mathrm{~m}^{2}$ and for shrubs it was $4 \times 4 \mathrm{~m}^{2}$. In total, we obtained 213 quadrats at 33 sampling sites (Appendix S1).

In the forest sites we recorded all species observed in the tree, shrub and herb layers, species abundance (the total number of species per unit area), canopy range, height and diameter in breast height of trees and shrubs, and height of herbs. The habitat conditions, such as slope, slope aspect, soil type and physical characteristics, grazing and other human disturbances were also recorded. In the grassland sites the species abundance and number of individuals, community coverage (the estimated percentage of quadrat surface area covered by a given species), height of herbs and shrubs, land-use type and intensity of human disturbance were recorded. In each site, moss polsters (forest only), litter and topsoil (forest and grassland) were taken randomly from each quadrat, and then mixed and sealed into a plastic box as one site sample. In total, 33 surface pollen samples were collected during the vegetation survey. 
( a ). Mean annual temperature $\left({ }^{\circ} \mathrm{C}\right)$

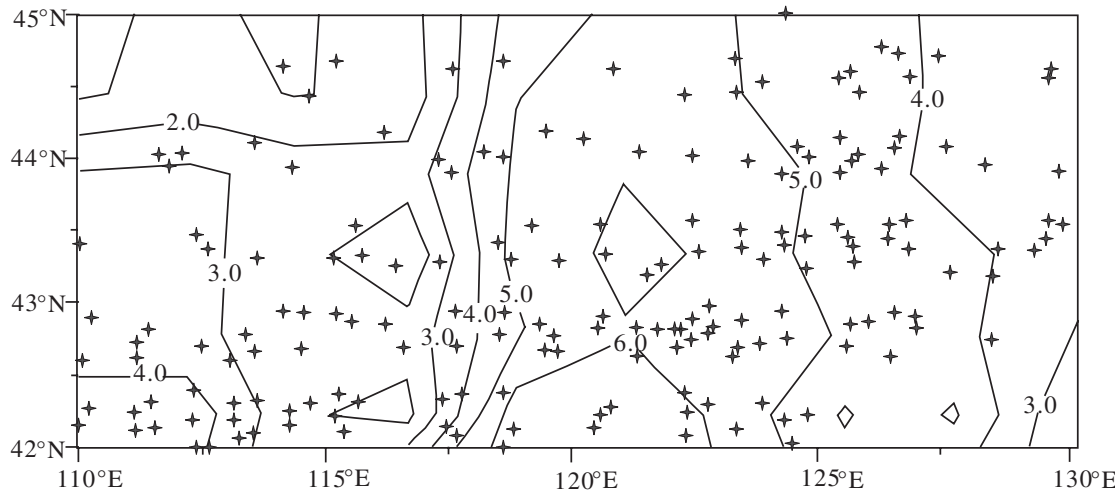

(b ). Mean annual precipitation( $\mathrm{mm}$ )

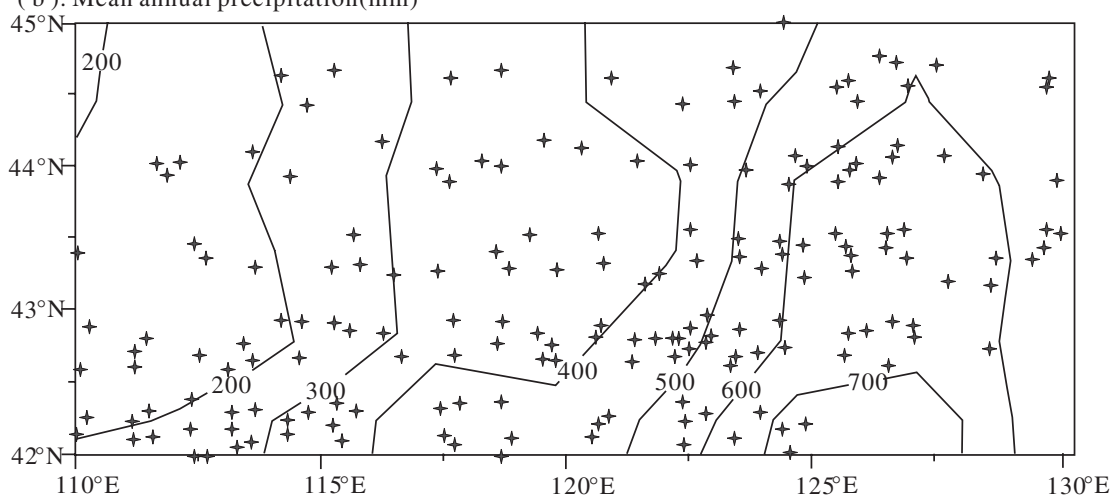

Figure 2 Contour maps of (a) mean annual temperature (MAT) and (b) mean annual precipitation (MAP) along the North-east China Transect (NECT). The asterisk indicates the locations of the meteorological stations.

\section{Laboratory treatments}

Surface pollen samples of $30 \mathrm{~g}$ each were sieved through 200-mm mesh screens to remove larger plant fragments, and then processed in the laboratory with heavy liquid separation and acetolysis. Treated pollen samples were then mounted in glycerol, and counted using $800 \times$ magnification with an Olympus microscope. For each sample, two or three slides were examined, and roughly 300 pollen grains were recorded. We excluded unknown and indeterminate pollen grains, such as broken, concealed or corroded pollen. Pollen percentages on the basis of the total pollen excluding spores were calculated (Fig. 3), using the Tilia/TiliaGraph software package (Grimm, 1991).

\section{Numerical analysis}

Ordination techniques have been widely used in analysing relationships between pollen taxa, vegetation data and environmental variables (Schofield et al., 2007; Ma et al., 2008). To determine whether to use linear or unimodal-based numerical methods, detrended correspondence analysis (DCA) is first performed to evaluate the gradient length of the first axis, which is measured in standard deviation (SD) units of species turnover (Jongman et al., 1995). A linear model with redundancy analysis (RDA) is most useful when the gradient length is $<3 \mathrm{SD}$, while a unimodal model with canonical correspondence analysis (CCA) is suitable when it is $>4 \mathrm{SD}$. For intermediate lengths, both models may be useful. In this study, the DCA of surface pollen samples along the NECT showed that the first axis had a gradient length of $<3 \mathrm{SD}$ (2.045), suggesting that species responses might be moderately linear (Jongman et al., 1995) and RDA would be preferred over CCA. Accordingly, patterns of modern local pollen variation related to environmental variables were explored by RDA and tested by associated statistical procedures. DCA and RDA were processed using the CANOCO software package (ter Braak \& Šmilauer, 2002).

MAT, MAP and a human disturbance index (HDI) were selected as environmental variables. The calculation of HDI was based on plant species composition in each plot (Liu et al., 2006, 2008a, b). Plant species were divided into three groups according to their relationships with human activities (Li, 1997). The high-disturbance plants (Group I), such as Setaria viridis, Plantago depressa and Convolvulus arvensis, mainly appear in heavily degraded steppes and forests, indicating strong human disturbance. The moderate-disturbance species (Group II), for example Artemisia frigida and Serratula centauroidus, mostly grow in moderately degraded steppes and forests and indicate medium disturbance. Group III refers to species with minimal or no degradation and slight human disturbance, such as Leymus chinensis, Lespedeza davarica, Stipa grandis and Stipa krylovii. First, an importance value (IV) was calculated for each species in each sample based on the sum of its relative abundance, relative coverage and relative height. Second, all species were divided into three groups, and weighted based on the dif- 


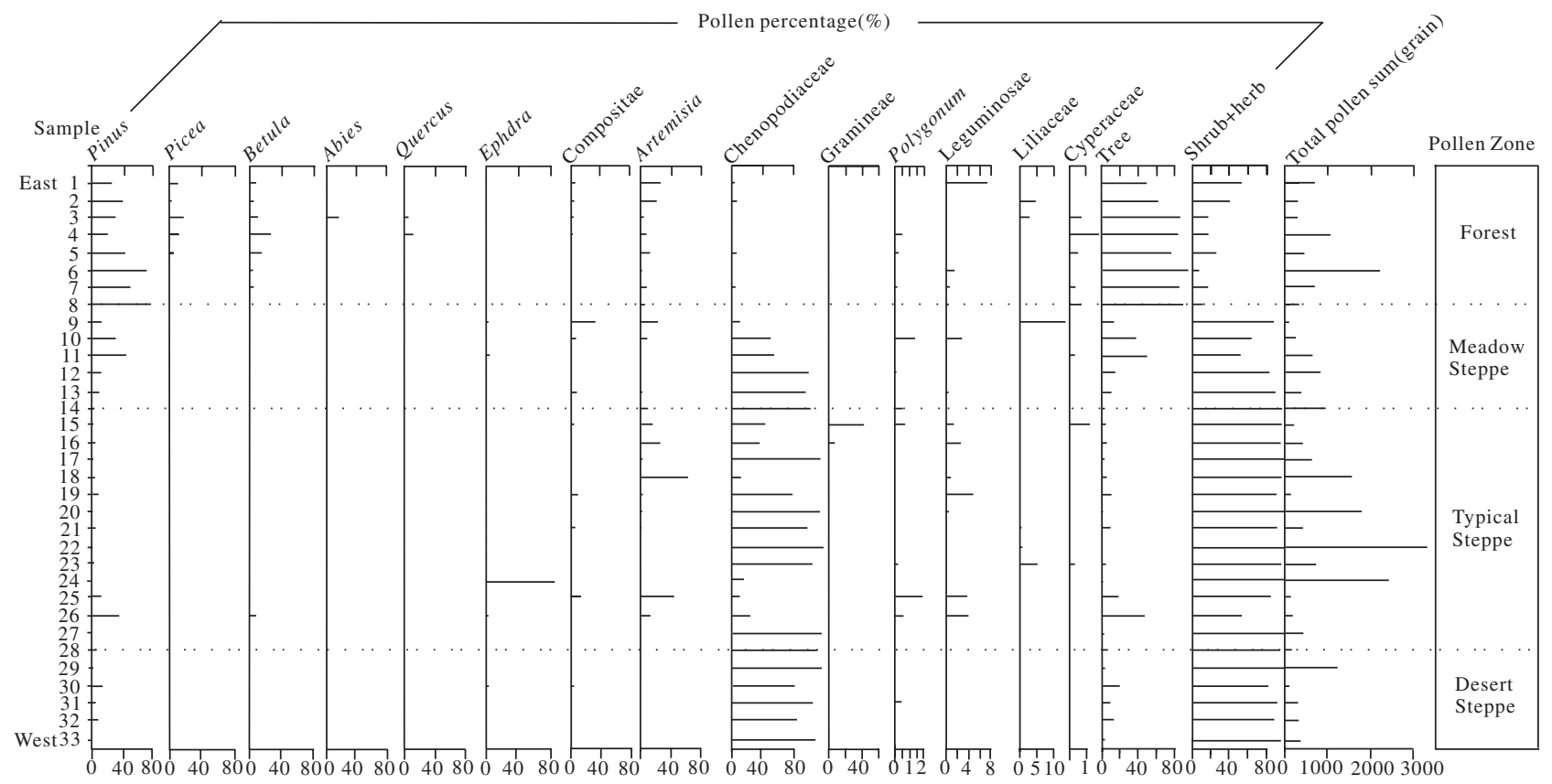

Figure 3 Surface pollen percentages and pollen zones along the North-east China Transect (NECT).

ferent degree of vegetation degradation and human disturbance as $1 / 3$ (Group I), 2/3 (group II) and 1 (Group III), respectively (Liu et al., 2006, 2008a, b).

The HDI is finally expressed as follows:

$\mathrm{HDI}=1 /(\mathrm{IV} 1 \times 1 / 3+\mathrm{IV} 2 \times 2 / 3+\mathrm{IV} 3)$

where IV1, IV2 and IV3 represent the IVs of species in the three classes, respectively (Liu et al., 2006, 2008a, b).

\section{RESULTS}

\section{Pollen assemblages of different vegetation zones}

In total, 65 pollen and spore taxa were identified in the 33 surface pollen samples. Forests are dominated by arboreal pollen, notably Pinus, Betula and Picea, whereas herbaceous pollen dominated the steppes. Chenopodiaceae and Artemisia are two common herbaceous types found in all samples of the study area. Ephedra, Leguminosae, Compositae, Gramineae, Polygonum, Umbelliferae, Liliaceae and Cyperaceae are often recorded. In addition, aquatic pollen (Typha) and fern spores (Polypodiaceae) were also counted.

Four pollen assemblage zones (Fig. 3) along the NECT are distinguished based on the characteristics of the surface pollen spectra in each of the four major vegetation types.

1. Forest zone (eight forest sites): tree pollen occupies the largest proportion (average of 76\%), dominated by Pinus (48.8\%) and Betula (8.6\%). Artemisia pollen accounts for $13.9 \%$ and Chenopodiaceae $2.3 \%$. Other pollen types are relatively rare. The pollen composition of the forest zone is summarized as a Pinus-Artemisia-Betula combination.
2. Meadow steppe zone (four steppe sites): the pollen assemblages are dominated by shrub and herb pollen, which account for more than $72 \%$ of the total pollen grains. Arboreal pollen percentages (mean 28\%) are much lower than in the forest vegetation zone. Relatively high percentages of Pinus $(27.1 \%)$ and Chenopodiaceae (44.9\%) are recorded. Pinus pollen grains, which are bisaccate and have high pollen production rates favourable to long-distance atmospheric transportation from the forest zone, are particularly over-represented (not representative of the real vegetation composition) in the meadow steppe, typical steppe and desert steppe zones, where few pine trees are present. Therefore it should be excluded from these pollen zones for further analysis, thereby preventing any distortion of the results. Artemisia accounts for $10.6 \%$ and Compositae $9 \%$. Therefore, the pollen composition of this zone is regarded as a Chenopodiaceae-Artemisia-Compositae assemblage.

3. Typical steppe zone (14 steppe sites): the pollen assemblage is characterized by high percentages of Chenopodiaceae and Artemisia. A maximum mean value of Artemisia (16.9\%) is recorded for the NECT, whereas the pollen percentage of Pinus $(7.0 \%)$ is relatively low and should again be excluded due to its long-distance transport. Chenopodiaceae pollen ranks in first place with an average of $56.9 \%$. Consequently, a Chenopodiaceae-Artemisia pollen combination is represented in this zone.

4. Desert steppe zone (seven sites): higher percentages of shrub and herb (82-98\%) still prevail in the pollen assemblage. The zone is marked by the largest portion of Chenopodiaceae of $88.5 \%$, but Artemisia is only $1.5 \%$. Exotic Pinus takes second place with a mean proportion of $5.1 \%$. Thus a Chenopodiaceae pollen assemblage is obvious in the desert steppe zone. 
Fern/herb $(\mathrm{F} / \mathrm{H})$
Artemisia/Chenopodiaceae $(\mathrm{A} / \mathrm{C})$
Arboreal pollen/non arboreal pollen (AP/NAP)
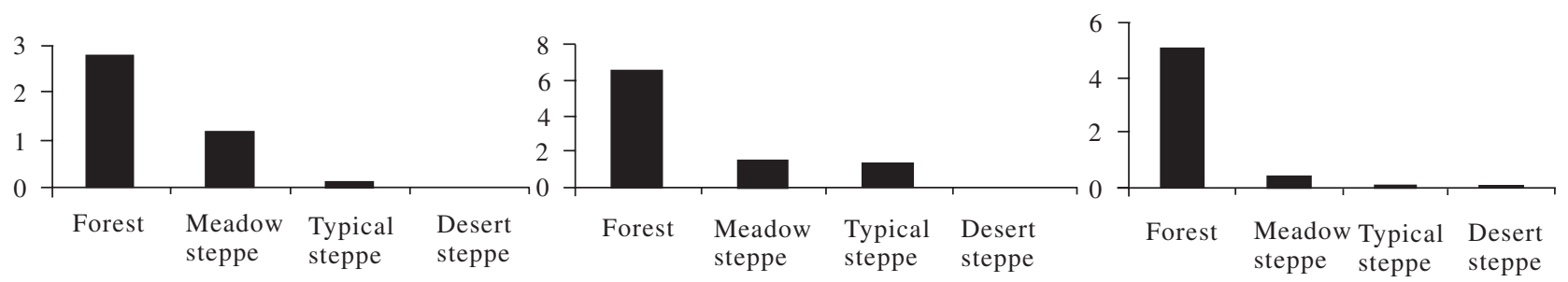

Figure 4 Ratios of the surface pollen in different vegetation zones.

\section{Pollen ratio}

Variations in the pollen ratios of fern/herb $(\mathrm{F} / \mathrm{H})$, Artemisial Chenopodiaceae (A/C) and arboreal pollen/non-arboreal pollen (AP/NAP) in the four vegetation zones (Fig. 4) demonstrate an obvious trend of pollen ratios. From forest and meadow steppe, through typical steppe, to desert steppe, the $\mathrm{F} / \mathrm{H}, \mathrm{A} / \mathrm{C}$ and AP/NAP ratios decrease greatly, which corresponds with the gradient change of both vegetation and climate. In addition, it relates to the spatial distribution of surface pollen of Artemisia, Chenopodiaceae, arboreal pollen and fern spores. The maximum value of Chenopodiaceae pollen occurs in the desert steppe zone and arboreal pollen and fern spores are dominant in the forest zone. Therefore, these three ratios all have maxima in the forest zone and minima in the desert steppe zone, which is consistent with the moisture gradient on the NECT.

\section{Pollen assemblages and environmental factors}

The RDA ordination for surface pollen percentage of 52 taxa (excluding fern spores) with environmental factors (Fig. 5) shows that the first axis (eigenvalue $=0.459$ ) accounts for $97.5 \%$ of the variation in environmental factors. Correlation between the first axis and species-environmental variables is 0.827 . The second axis (eigenvalue $=0.008$ ) explains only $1.7 \%$ of the variation in data set. Correlation between the second axis and species-environmental variables is 0.290 .

MAP has the highest correlation coefficient (0.93) with the first axis, whereas MAT has a high coefficient (0.91) with the second axis (Fig. 5a). It is evident that the first two axes represent the gradients of MAP and MAT, respectively, as indicated by the scores of pollen variables. MAP and MAT are therefore the primary factors controlling variations of surface pollen data on the NECT. Furthermore, the surface pollen assemblages are different in the four vegetation types (Fig. 5a). Consequently, from forest to desert steppe, the change in MAP corresponds with the gradient change of the surface pollen assemblage.

The HDI, however, shows smaller correlations with two axes ( -0.49 and 0.62$)$, implying a less significant influence on surface pollen distribution. Therefore, the effect of human disturbance on surface pollen spectra is not significant (Fig. 5).

With respect to pollen taxa, on the first axis arboreal pollen (Picea, Pinus and Quercus) with high MAP have high scores whereas those from desert steppe (Chenopodiaceae) with rela- tively low MAP have low scores. Pollen taxa from meadow and steppe have medium scores (Fig. 5b). Arboreal pollen taxa have a higher correlation with MAP than with other environmental factors, indicating that arboreal pollen percentage is strongly influenced by precipitation changes. In contrast, there is a negative correlation between Chenopodiaceae pollen and MAP (Fig. 5b). Chenopodiaceae percentages rise gradually in association with increasing aridity from forest to meadow steppe, to typical steppe, to desert steppe. However, human influences are also reflected by the changes in Chenopodiaceae and Gramineae pollen as evidenced by the good correlation between two pollen taxa and HDI (Fig. 5b).

The RDA results of sampling sites according to different HDI values are shown in Fig. 5(c). Highly disturbed sampling sites are well distinguished from sampling sites with low and medium HDI, indicating that strong human disturbance can be identified from the modern pollen assemblage in spite of different vegetation types in the NECT. The strongest human disturbance occurs in Sites $16(\mathrm{HDI}=3.50)$ and $15(\mathrm{HDI}=2.72)$, followed by Sites $8,10,13,14,17,19,28$ and 29.

\section{DISCUSSION}

\section{Surface pollen assemblages and precipitation gradient}

Surface pollen assemblages along the NECT provide a good indication of vegetation changes. The relationships of modern pollen assemblages to environmental variables were well investigated by RDA. Strong positive correlations were found between MAP and arboreal pollen such as Pinus, Quercus and Picea, and markedly negative correlations occurred between MAP and Chenopodiaceae. Consequently, precipitation mainly affected surface pollen assemblages in the NECT through zonal vegetation patterns. Furthermore, in the RDA space pollen taxa along the NECT could ordinate into four bioclimatic groups mainly based on moisture conditions in terms of values of the first axis. Pollen taxa in Group 1 are characterized by moisturefavouring trees, such as Pinus, Picea, Quercus and Fraxinus. Pollen taxa in Group II are Compositae, Umbelliferae and Artemisia, requiring both moderate temperature and moisture. Group III, including Chenopodiaceae, is the main component of 
( a )

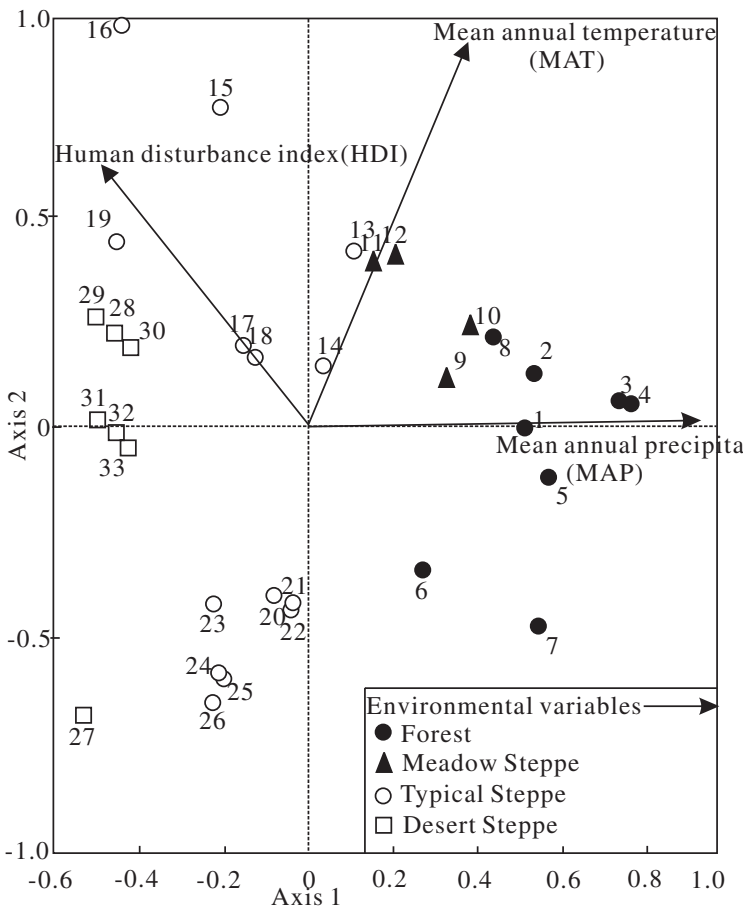

(c)

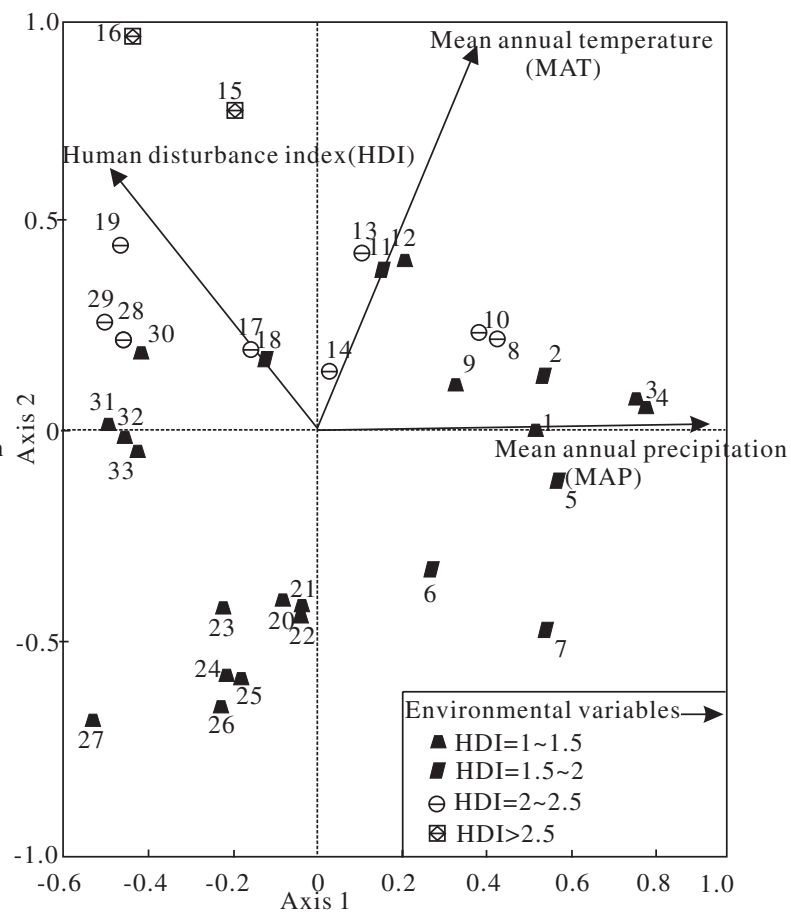

( b )

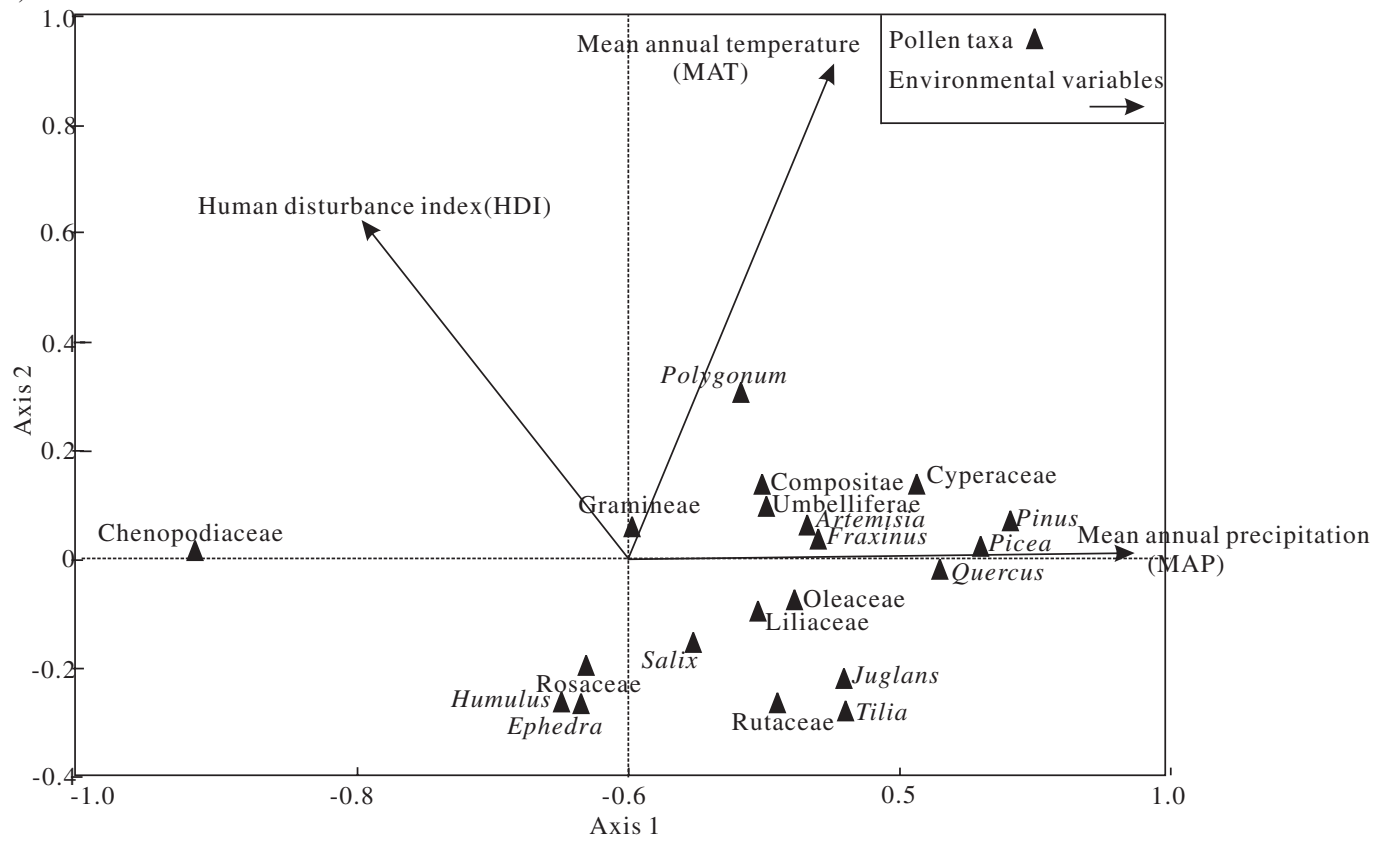

Figure 5 Redundancy analysis (RDA) results of surface pollen sampling sites and pollen taxa: (a) surface pollen sampling sites indicated by vegetation types; (b) surface pollen taxa; (c) surface pollen sampling sites indicated by the human disturbance index (HDI).

the xeromorphic desert. Pollen taxa of Group IV contain mesoxerophytes like Rosaceae, Humulus and Ephedra.

\section{Surface pollen assemblages and HDI}

RDA ordination reveals that the HDI was significantly correlated with Chenopodiaceae pollen, which agrees with the findings from Liu et al. (2006). Gramineae, which obviously have a low representation, because their pollen percentages are generally lower than their plant coverages in quadrats (Liu et al., 2008a), are also strongly correlated to HDI. Research has also shown that the under-representation of Gramineae in the surface pollen samples in steppe is actually the outcome of human-induced disturbance such as overcultivation and overgrazing (Ma et al., 2008). Furthermore, correlation analyses of Chenopodiaceae and HDI in four vegetation zones indicate that 
Chenopodiaceae percentages in the desert steppe zone $(R=0.89$, $P<0.05)$ are more easily affected by human disturbance than in other zones (typical steppe: $R=0.27, P=0.39$; meadow steppe: $R=0.93, P=0.07$; forest: $R=0.10, P=0.8$ ).

\section{Fossil proxies of human disturbances in northern sand lands}

The history of desertification and sandification derived from pollen records in the Horqin and the Mu Us Sand Land of Inner Mongolia, two of the most severely desertified areas in northeastern China, also showed the human disturbances related to pollen records in sandy habitats, which could be compared with surface pollen analysis.

The $\mathrm{Mu}$ Us Desert $\left(36^{\circ} 49^{\prime}-40^{\circ} 12^{\prime} \mathrm{N}, 106^{\circ} 30^{\prime}-111^{\circ} 56^{\prime} \mathrm{E}\right)$, with an area of about 40,000 $\mathrm{km}^{2}$, stretches from Inner Mongolia in the north to Shaanxi and Ningxia in the south with a temperate continental climate in a semi-arid area (Fig. 1). Pollen and charcoal records from a $238 \mathrm{~cm}$ manually excavated palaeosol profile at Yangjiawan village $\left(39^{\circ} 28^{\prime} 08^{\prime \prime} \mathrm{N}\right.$ and $\left.110^{\circ} 09^{\prime} 92^{\prime \prime} \mathrm{E}\right)$ reveal the rapid replacement of pollen from coniferous and broadleaved mixed forest pollen with Chenopodiaceae at 2400 cal yr BP, suggesting a climate shift to drier conditions. The dark loess that originally developed during the Middle Holocene, was destroyed and seriously eroded as the sand dunes reactivated again at $2400 \mathrm{cal} \mathrm{yr} \mathrm{вP.} \mathrm{The} \mathrm{A/C} \mathrm{pollen} \mathrm{ratio} \mathrm{in} \mathrm{the} \mathrm{palaeosol}$ profile rapidly was reduced from 158.5 to 15 .

Many ancient relics were discovered nearby, such as stone axes, stout-legged tripods and tripodal urns, indicating the impacts of human activities (Xu et al., 2002). As proposed by Sun (2000), large-scale land cultivation during the West Han Period (206 BC-AD 8) contributed to the great decrease in the natural vegetation cover in the $\mathrm{Mu}$ Us Sand Land. Historical records indicate that up to 1 million people migrated from central China to the Ordos Plateau, including the Mu Us Desert and the Hobq Desert, between 127 and 111 вс (Wang, 1985). Accordingly, primitive farming began to develop in this region (Fang et al., 1998) and may have contributed to landscape change.

Charcoal, as a fossil indicator of fire, is produced by the incomplete burning of plant material. The concentration of microscopic charcoal (with size fractions $<100 \mu \mathrm{m}$ ) can be taken as an indication of regional fire occurrence caused naturally or intentionally by humans (MacDonald et al., 1991). A dramatic increase in microcharcoal concentrations (>5000 grains $\mathrm{g}^{-1}$ ) during the period 2700-2400 cal yr вP in the Yangjiawan profile, associated with the above archaeological (Xu et al., 2002) and historical record (Wang, 1985), provides strong evidence for human-related burning activities. Therefore, extremely high percentages of Chenopodiaceae most likely imply that changes in pollen taxa assemblages in the Mu Us Sand Land were affected by human disturbance to local vegetation.

The Horqin Sand Land $\left(42^{\circ} 41^{\prime}-45^{\circ} 15^{\prime} \mathrm{N}, 118^{\circ} 35^{\prime}-123^{\circ} 30^{\prime} \mathrm{E}\right)$ is located in Inner Mongolia, Liaoning and Jilin provinces with a temperate continental semi-arid monsoon climate. Pollenbased records of two exposed profiles from Zhamu $\left(43^{\circ} 24^{\prime} \mathrm{N}\right.$, $\left.125^{\circ} 26^{\prime} \mathrm{E}\right)$ (Yang, 1995) and Maili $\left(42^{\circ} 52^{\prime} \mathrm{N}, 122^{\circ} 53^{\prime} \mathrm{E}\right)$ wetlands (Ren, 1999) situated in the Horqin Left North Banner revealed a detailed history of soil desertification and vegetation degradation in the Horqin Sand Land. The Zhamu profile showed a decline in woody and aquatic plants from 2400-2100 cal yr вр, whereas Artemisia, Chenopodiaceae, Gramineae, Convolvulus, Leguminosae and other pollen types indicative of human activity (like weeds and cereal-type pollen) such as Humulus and Molvaceae (Li et al., 2008) rose to $90 \%$ of total pollen (Yang, 1995). Pollen analyses from the Maili profile indicated that since $3100 \mathrm{cal}$ yr вр arboreal pollen dominated by Quercus mongolica declined rapidly, whereas herbaceous taxa, especially Artemisia and Chenopodiaceae, increased gradually. Furthermore, the rise of Chenopodiaceae lagged behind that of Artemisia. During the period, the fixed sand dunes were partially turned into semi-fixed sand dunes due to the removal of vegetation. Subsequently, they were converted into semi-moving dunes, and even moving sand dunes.

Archaeological relics and documentary records indicate that only a few groups of nomads and hunter visited in the Horqin Left North Banner at 5000 cal yr вр when agriculture was widely practiced by early settlers on the Liaodong Peninsula and in Hebei Province (Tan, 1982; Ren \& Zhang, 1998). Agriculture had shifted north to the south-eastern Horqin Sand Land and the neighbouring regions since $3000 \mathrm{cal} \mathrm{yr} \mathrm{вр,} \mathrm{where} \mathrm{the} \mathrm{earliest}$ native cultivation relics were found (the 'Gaotaishan culture', 3350-2965 cal yr вр) (Tian, 1988; Xin, 1988; Tong, 1989; Zhang, 1991). Many ancient relics were discovered nearby, including stone knives, stone axes, stone sickles, a millstone plate, millstone stick and tripodal urns, all suggesting that agriculture played an important role in the state's economy during this period (Tian, 1988; Xin, 1988). Archaeological investigations have identified a dramatic increase in archaeological sites occurred since $3000 \mathrm{cal} \mathrm{yr} \mathrm{BP,} \mathrm{indicating} \mathrm{a} \mathrm{significant} \mathrm{rise} \mathrm{in}$ human population and agricultural activities in the Horqin Left North Banner (Ren, 1999). Therefore, the increase in population and large-scale land cultivation contributed to soil desertification and the degeneration of vegetation in the study area (Ren, 1999).

This conclusion was further confirmed by increasing charcoal concentrations in the Maili profile after $2800 \mathrm{cal}$ yr вр (Ren, 1999). Generally, microcharcoal is not only an indicator of distal burning but also reflects local fire activity. Furthermore, macrocharcoal (particles $>100 \mu \mathrm{m}$ ) is a distinct marker of local fire production (Hounslow \& Chepstow-Lusty, 2002). Therefore, variations in macrocharcoal concentration can be used to reconstruct fire frequency and have been used to explore the role of human-related changes in fire regimes (Whitlock \& Larsen, 2001). A remarkable increase in both macrocharcoal and microcharcoal concentrations at the Maili site since $2800 \mathrm{cal} \mathrm{yr} \mathrm{вр,}$ with a large peak at $1090 \mathrm{cal} \mathrm{yr} \mathrm{BP}$, in association with increased human populations (Tian, 1988; Xin, 1988; Tong, 1989; Zhang, 1991) and combined with a large number of archaeological remains (grinding stones, ceramics, and wooden artefacts) (Tian, 1988; Xin, 1988) in these deposits, provide supporting evidence for the anthropogenic use of fire. Accordingly, this also 
corroborates the large increase in Chenopodiaceae pollen indicative of human-caused vegetation degradation in the Horqin Sand Land. In addition, there is evidence from North America that chenopods played an important role in prehistoric agriculture (Leach et al., 1996). An abundance of Chenopodiaceae pollen since $3000 \mathrm{cal} \mathrm{yr} \mathrm{вP} \mathrm{in} \mathrm{a} \mathrm{lake-sediment} \mathrm{core} \mathrm{from}$ Laguna Zoncho in southernmost Costa Rica is also a signal of high human disturbance, possibly also related to prehistoric cultivation (Clement \& Horn, 2001).

\section{A/C pollen ratio for environmental reconstructions}

On the NECT, the ratios of $\mathrm{F} / \mathrm{H}, \mathrm{A} / \mathrm{C}$ and $\mathrm{AP} / \mathrm{NAP}$ represent the vegetation gradient from forest to meadow steppe, steppe and desert steppe, as well as the precipitation gradient from the humid east to the arid west. The A/C ratio, first used by El-Moslimany (1990), has been regarded as an indicator of climatic aridity (Wünnemann et al., 2006; Herzschuh, 2007). As proposed by Sun et al. (1994), it could also be used as an index to distinguish steppe and desert vegetation in semi-arid and arid areas. In the study of the NECT, the A/C ratio is $>5$ in the forest zone, $>1$ in meadow steppe and typical steppe areas, and $<1$ in the desert steppe zone, which partially agrees with Sun et al. (1994) and Chen et al. (2006).

However, at a local scale, an increase in the percentage of Chenopodiaceae caused by human disturbance leads to a decrease in the $\mathrm{A} / \mathrm{C}$ ratio. Pollen and phytolith records of a $175-\mathrm{cm}$ peat profile $\left(44^{\circ} 25.06^{\prime} \mathrm{N}, 86^{\circ} 01.26^{\prime} \mathrm{E}\right)$ at Caotan Lake, northern Xinjiang, north-eastern China showed that the climate was characterized by alternate periods of wet and dry conditions since $2500 \mathrm{cal} \mathrm{yr}$ вр, but the $\mathrm{A} / \mathrm{C}$ pollen ratios continued to decrease. The continued decrease of $\mathrm{A} / \mathrm{C}$ was not linked to climatic drying but probably reflected human disturbance at Caotan Lake (Zhang et al., 2009). It is obvious that the A/C pollen ratio is a good indicator of climate change and an index for distinguishing forest, steppe and desert vegetation in the NECT. However, when human disturbance is involved in the interpretation of pollen data for the reconstruction of palaeoclimatic and anthropogenic biomes based on fossil pollen data, the ratio should be used carefully.

\section{Ecotones in the NECT and human disturbance}

The current land-use pattern in the NECT is forest, forestagriculture ecotone, agriculture, agriculture-pasture ecotone and pastoral areas, from east to west (Zhang et al., 1997). Almost all the sampling sites have been affected by various degrees of human disturbance, but RDA results showed that most sampling sites with higher HDI values occurred in three ecotones along the NECT, which are regarded as regions sensitive to climate and vegetation changes (Di Castri et al., 1988). Sampling Sites 8 and 10 are located in the forest-agriculture ecotone, Sites 13-17 and 19 in the ecotone between agriculture and pasture, and Sites 28 and 29 in the ecotone between typical steppe and desert steppe.
Sampling Site 16 with the highest HDI values is located in the Horqin Sand Land, which is a typical ecotone of farming and grazing in the transition zone of the north-east plain and the Inner Mongolian Plateau. The landscape is characterized largely by low, open shrubs dominated by Caragana microphyll on shifting and semi-shifting dunes and fixed dunes. The history of desertification and sandification derived from above fossil pollen and charcoal records, historical documents and archaeological evidence in the Horqin Sand Land have suggested that human disturbance has contributed strongly to soil desertification and vegetation degeneration since $3000 \mathrm{cal} \mathrm{yr} \mathrm{вр.} \mathrm{Therefore,}$ our findings show that intensive human activities could result in human-caused vegetation degradation in this ecotone, which is considered to be a sensitive and unstable region. Protection and management practices should give more attention to this ecotone to prevent processes of desertification and in land-use planning.

\section{CONCLUSIONS}

The precipitation gradient is the primary factor contributing to changes in surface pollen assemblages along the NECT. Surface and fossil pollen and archaeological and historical records in northern China suggest that a large expansion of Chenopodiaceae pollen implies the degradation of vegetation under the impact of human activities, especially in sandy habitats. The A/C ratio is a good indicator of climate change and an index for distinguishing forest, steppe and desert vegetation along the NECT. However, it should be used carefully when human disturbance is involved in reconstructing palaeoclimate and anthropogenic biomes based on fossil pollen records. Our study of surface pollen assemblages along a precipitation and land-use gradient in the NECT therefore provides potentially valuable analogues for human-induced vegetation change in order to understand the associated changes in the world's anthropogenic biomes, and hence their conservation and management in the anthropogenic epoch.

\section{ACKNOWLEDGEMENTS}

This research was jointly funded by the National Natural Science Foundation of China (NSFC grant nos. 30590383, 40601104 and 40972212), the Scientific Research Foundation for the Returned Overseas Chinese Scholars, China Ministry of Education, and the German Research Foundation (DFG Schwerpunktprogramm 1266). We thank other team members of the 2006 NECT survey (Sandy Harrison, Colin Prentice, Peter HarrisonPrentice, Lucy Harrison-Prentice, Ting-Ting Meng, Juan Wang, Han Wang, Ting-Ting Yao, Sheng-Jun Ji, and Xun Tian) for their help in collecting samples. We also thank Jennifer R. Marlon and Mitchell J. Power for their help with the improvement of the English language. Special thanks are given to Liu Hongyan for his vegetation data and suggestions in preparing this manuscript. 


\section{REFERENCES}

Alessa, L. \& Chapin, F.S., III (2008) Anthropogenic biomes: a key contribution to earth-system science. Trends in Ecology and Evolution, 23, 529-531.

ter Braak, C.J.F. \& Šmilauer, P. (2002) CANOCO reference manual and CanoDraw for Windows user's guide: software for canonical community ordination (version 4.5). Microcomputer Power, Ithaca, NY.

Bradshaw, R.H.W. (2008) Detecting human impact in the pollen record using data-model comparison. Vegetation History and Archaeobotany, 17, 597-603.

Chen, H., Zhao, D.S., Lu, X.M., Li, Y.C., Xu, Q.H., Li, S.C. \& Ouyang, H. (2006) Surface pollen in the east of Qaidam Basin. Journal of Geographical Sciences, 16, 439-446.

Clement, R.M. \& Horn, S.P. (2001) Pre-Columbian land-use history in Costa Rica: a 3000-year record of forest clearance, agriculture and fires from Laguna Zoncho. The Holocene, 11, 419-426.

Dearing, J.A. (2006) Climate-human-environment interactions: resolving our past. Climate of the Past, 2, 187-203.

Di Castri, F., Hansen, A.J. \& Holland, M.M. (1988) A new look at ecotones: emerging international projects on landscape boundaries. Biology International, Special Issue 17. IUBS, Paris.

Ellis, E.C. \& Ramankutty, N. (2008) Putting people in the map: anthropogenic biomes of the world. Frontiers in Ecology and the Environment, 6, 439-447.

El-Moslimany, A.P. (1990) Ecological significance of common nonarboreal pollen: examples from drylands of the Middle East. Review of Palaeobotany and Palynology, 64, 343-350.

Fang, H.J., Yang, X.M., Zhang, X.P. \& Liang, A.Z. (2006) Using ${ }^{137} \mathrm{Cs}$ tracer technique to evaluate erosion and deposition of black soil in Northeast China. Pedosphere, 16, 201-209.

Fang, X.Q., Zhang, W.B. \& Zhang, L.S. (1998) The land use arrangement of China in the Holocene Megathermal Period and its significance. Journal of Natural Resources, 13, 16-22 (in Chinese).

Grimm, E.C. (1991) TILIA and TILIA GRAPH. Illinois State Museum, Springfield, IL.

Herzschuh, U. (2007) Reliability of pollen ratios for environmental reconstructions on the Tibetan Plateau. Journal of Biogeography, 34, 1265-1273.

Hounslow, M.W. \& Chepstow-Lusty, A. (2002) Magnetic properties of charcoal rich deposits associated with a Roman bathhouse, Butrint (southern Albania). Physics and Chemistry of the Earth, 27, 1333-1341.

Jongman, R.H.G., Braak, C.J.F. \& van Tongeren, O.F.R. (1995) Data analysis in community and landscape ecology. Cambridge University Press, Cambridge.

Koch, G.W., Scholes, R.J., Steffen, W.L., Vitousek, P.M. \& Walker, B.H. (1995) The IGBP terrestrial transects: science plan. IGBP, Stockholm.

Leach, J.D., Holloway, R. \& Almarez, F. (1996) Prehistoric evidence for the use of Chenopodium (goose foot) from the Hueco Bolson of west Texas. Texas Academy of Science, 48, 163-165.
Li, B. (1997) The range degradation in northern China and its preventive strategy. Scientia Agricultura Sinica, 30, 1-9 (in Chinese).

Li, Y.Y., Zhang, X.S. \& Zhou, G.S. (2000) Quantitative relationships between vegetation and several pollen taxa in surface soil from North China. Chinese Science Bulletin, 45, 15191523.

Li, Y.Y., Zhou, L.P. \& Cui, H.T. (2008) Pollen indicators of human activity. Chinese Science Bulletin, 53, 1281-1293.

Liu, H.Y., Wang, Y., Tian, Y.H., Zhu, J.L. \& Wang, H.Y. (2006) Climatic and anthropogenic control of surface pollen assemblages in East Asian steppes. Review of Palaeobotany and Palynology, 138, 281-289.

Liu, H.Y., Wei, F.L., Liu, K., Zhu, J.L. \& Wang, H.Y. (2008a) Determinants of pollen dispersal in the East Asian steppe at different spatial scales. Review of Palaeobotany and Palynology, 149, 219-228.

Liu, H.Y., Yin, Y., Ren, J., Tian, Y.H. \& Wang, H.Y. (2008b) Climatic and anthropogenic controls of topsoil features in the semi-arid East Asian steppe. Geophysical Research Letters, 35, L04401, doi:10.1029/2007GL032980.

Ma, Y.Z., Liu, K.B., Feng, Z.D., Sang, Y.L., Wang, W. \& Sun, A.Z. (2008) A survey of modern pollen and vegetation along a south-north transect in Mongolia. Journal of Biogeography, 35, 1512-1532.

MacDonald, G.M., Larsen, C.P.S., Szeicz, J.M. \& Moser, K.A. (1991) The reconstruction of boreal forest fire history from lake sediments: a comparison of charcoal, pollen, sedimentological, and geochemical indices. Quaternary Science Reviews, 10, 53-71.

Ni, J. (2003) Plant functional types and climate along a precipitation gradient in temperate grasslands, north-east China and south-east Mongolia. Journal of Arid Environments, 53, 501516.

Ni, J. \& Wang, G.H. (2004) The Northeast China Transect (NECT): ten-year synthesis and future challenges. Acta Botanica Sinica, 46, 379-391.

Ni, J. \& Zhang, X.S. (2000) Climate variability, ecological gradient and the Northeast China Transect (NECT). Journal of Arid Environments, 46, 313-325.

Prentice, I.C., Jolly, D. \& BIOME 6000 Participants (2000) MidHolocene and glacial-maximum vegetation geography of the northern continents and Africa. Journal of Biogeography, 27, 507-519.

Ren, G.Y. (1999) Influence of human activities on the late Holocene vegetation changes at Maili, northeast China. Scientia Geographica Sinica, 19, 42-48 (in Chinese).

Ren, G.Y. (2007) Changes in forest cover in China during the Holocene. Vegetation History and Archaeobotany, 16, 119-126.

Ren, G.Y. \& Zhang, L.S. (1998) A preliminary mapped summary of Holocene pollen data for northeast china. Quaternary Science Reviews, 17, 669-688.

Schofield, J.E., Edwards, K.J. \& McMullen, A.J. (2007) Modern pollen-vegetation relationships in subarctic southern Greenland and the interpretation of fossil pollen data from the Norse landnám. Journal of Biogeography, 34, 473-488. 
Sun, J.M. (2000) Origin of eolian sand mobilization during the past 2300 years in the Mu Us Desert, China. Quaternary Research, 53, 78-88.

Sun, X.J., Du, N.Q., Weng, C.Y., Lin, R.F. \& Wei, K.Q. (1994) Paleovegetation and paleoevironment of Manasi lake, Xinjiang, NW China during the last 14,000 years. Quaternary Sciences, 3, 239-248.

Tan, Q.X. (1982) Historic atlas of China, Vol. 1. China Cartography Press, Beijing (in Chinese).

Tian, Y. (1988) Discussion on relative questions and cultural types of Shunshantun site. Journal of Liaohai Cultural Relics, 2, 68-77 (in Chinese).

Tong, Z.C. (1989) Selected works of the archaeology of northeast China and the neolithic archaeology of China. Cultural Relics Publishing House, Beijing (in Chinese).

Wang, S.Y. (1985) Historical changes of pastoral and farming economy in the Ordos Plateau and its impacts on natural environment. Historical Geography, 5, 11-24. (in Chinese).

Whitlock, C. \& Larsen, C.P.S. (2001) Charcoal as a fire proxy. Tracking environmental change using lake sediments, Vol. 3 (ed. by J.P. Smol, H.J.B. Birks and W.M. Last), pp. 75-97. Kluwer Academic Publishers, Dordrecht.

Wünnemann, B., Mischke, S. \& Chen, F.H. (2006) A Holocene sedimentary record from Bosten Lake, China. Palaeogeography, Palaeoclimatology, Palaeoecology, 234, 223-238.

Xin, Z.S. (1988) A preliminary excavation of shunshantun site in the Bronze Age. Journal of Liaohai Cultural Relics, 1, 27-40 (in Chinese).

Xu, Q.H., Kong, Z.C., Chen, X.D., Yang, X.L., Liang, W.D. \& Sun, L.M. (2002) Discussion on the environment changes and the effects of human impacts in the east Ordos Plateau since 4000a BP. Quaternary Sciences, 22, 105-112 (in Chinese).

Yang, Y.X. (1995) Study on the formation and development of mire and paleoenvironment changes since the Holocene in the northeast region. $\mathrm{PhD}$ Thesis, Institute of Geography, the Chinese Academy of Sciences. Beijing, China.

Zhang, B.Z. (1991) Preliminary studies on the historical changes and the reasons in the Horqin Sandy Land. Proceedings of archaeological culture in the east area of Inner Mongolia (ed. by Institute of Cultural and Historical Relics and Archaeology, Inner Mongolia Autonomous Region), pp. 140-167. Ocean Press, Beijing (in Chinese).

Zhang, X.S., Gao, Q., Yang, D.A., Zhou, G.S., Ni, J. \& Wang, Q. (1997) A gradient analysis and prediction on the North-East China Transect (NECT) for global change study. Acta Botanica Sinica, 39, 785-799.

Zhang, Y., Kong, Z.C., Yan, S., Yang, Z.J. \& Ni, J. (2009) 'Medieval Warm Period' on the northern slope of central Tianshan
Mountains, Xinjiang, NW China. Geophysical Research Letters, 36, L11702. doi: 10.1029/2009GL037375

Zhang, Y.J. \& Zhou, G.S. (2008) Terrestrial transect study on driving mechanism of vegetation changes. Science in China Series D: Earth Sciences, 51, 984-991.

Zhao, S.D., Gao, R.P. \& Tao, Y. (1992) Historical change and future development of Chinese vegetation. Global Change Studies of China (ed. by D.Z. Ye and P.Q. Chen), pp. 170-180. China Earthquake Press, Beijing, China (in Chinese).

\section{SUPPORTING INFORMATION}

Additional Supporting Information may be found in the online version of this article:

Appendix S1 Information on 33 surface pollen sampling sites along the North-east China Transect (NECT).

As a service to our authors and readers, this journal provides supporting information supplied by the authors. Such materials are peer-reviewed and may be re-organized for online delivery, but are not copy-edited or typeset. Technical support issues arising from supporting information (other than missing files) should be addressed to the authors.

\section{BIOSKETCHES}

Yun Zhang is an associate professor in palaeoecology at the Institute of Botany, Chinese Academy of Sciences. Her research interests include Quaternary environmental changes and Quaternary palaeoecology using multiple proxies and historical documents.

Zhaochen Kong is a professor in the Institute of Botany, Chinese Academy of Sciences. His research interests are in palaeoclimatology and palaeovegetation in China.

Jian Ni is a professor in the Institute of Botany, Chinese Academy of Sciences and the Alfred Wegener Institute for Polar and Marine Research, Germany. His research interests include large-scale synthesis and modelling of vegetation patterns and functions, palaeovegetation reconstruction and simulation, and vegetation science.

Editor: Wolfgang Cramer 